\title{
Original
}

\section{A Novel Method for Estimating Viable Salmonella Cell Counts Using Real-Time PCR}

(Received February 23, 2006)

\author{
Hiroshi FujıKawa ${ }^{\dagger}$ Yukako Shimojima and Kazuyoshi Yano \\ (Department of Microbiology, Tokyo Metropolitan Institute of Public Health: 3-24-1, \\ Hyakunin-cho, Shinjuku-ku, Tokyo $169-0073$, Japan; ${ }^{\dagger}$ Corresponding author)
}

\begin{abstract}
A novel method for estimating viable Salmonella Enteritidis cell counts with $5^{\prime}$-nuclease real-time PCR was developed in this study. Our method was based on the increase kinetics of the target DNA region $(i n v \mathrm{~A})$ of the microorganism growing in a food/clinical sample in a culture medium during incubation. The index of increase in the target DNA region studied here was threshold cycle, $C_{\mathrm{T}}$. A test Salmonella strain was grown in buffered peptone water at the optimal temperature $\left(39^{\circ} \mathrm{C}\right)$. As Salmonella cells were grown, the value of $C_{\mathrm{T}}$ decreased with time, generating a downward sigmoidal curve. The slope of the curve was constant at various initial cell concentrations. With higher initial cell concentration, the $C_{\mathrm{T}}$ value evaluated from the slope at a given time was lower. With this relationship, a novel method for estimating the initial viable cell concentration of a sample was developed. Dead Salmonella cells or bacteria other than the target cell caused deviation in the $C_{\mathrm{T}}$ curve. Incubation in a selective media suppressed the deviation caused by other bacterial cells. We think that this method could be applied to many other microorganisms cultivable in a suitable medium.
\end{abstract}

Key words: real-time PCR; viable cell counts; Salmonella; estimation method; threshold cycle

\section{Introduction}

Recently polymerase chain reaction (PCR) technologies in the microbiological field, as well as other biological fields, have progressed remarkably. In conventional PCR replication of the target DNA fragment is qualitatively detected as an electrophoretic band. Realtime PCR, especially TaqMan real-time PCR, has some great advantages over conventional $\mathrm{PCR}^{11}$. The advantages include the ability to detect replication quantitatively with a high specificity, by the introduction of the TaqMan probe labeled with reporter and quencher dyes into the PCR system. A number of researchers have developed TaqMan real-time PCR methods to detect microbiological pathogens in foods and/or clinical samples ${ }^{2)-5)}$.

However, some problems remain in PCR, even the TaqMan real-time PCR. One of them is an inability to distinguish between live and dead cells ${ }^{1}$. That is, when a food or clinical sample contains both dead and live target cells, the TaqMan real-time PCR detects both. Thus, there is a possibility that the cell counts estimated with the real-time PCR are higher than the real live cell counts. Even if the target cells in the sample were all dead cells, the PCR would give a positive reaction. This can be a serious problem in foods, where processing may destroy microbial cells, but leave their DNA relatively intact ${ }^{1)}$. DNA itself is heat-stable; samples are heated for DNA extraction prior to PCR, as shown in Materials and Methods. If this problem can be solved, PCR would be a much more reliable tool.

On the other hand, enrichment of microorganisms in a sample with a nutrient medium (broth) has been recognized to be a useful procedure for subsequent

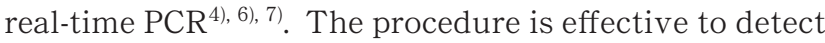
a small number of target cells in a sample, but this is still qualitative. No studies have indicated that enrichment might have the potential to allow estimation of the number of viable target cells in a sample. Recently, we found that the total viable cell counts of bacteria contaminating a food sample can be successfully estimated by measuring the increase kinetics of the ATP level of the sample incubated in nutrient broth ${ }^{8), 9)}$. Here, the ATP level of the sample increases with the bacterial growth in the sample during the incubation. Using this estimation method, in the present study, we aimed to develop a novel procedure for viable cell counts estimation of the target microorganism with the TaqMan real-time PCR. We chose Salmonella enterica serovar Enteritidis cells as the target, since it is one of the major agents of bacterial food poisoning outbreaks worldwide.

\section{Materials and Methods}

\section{Bacterial strain}

A Salmonella enterica serovar Enteritidis strain 04137 was isolated from a Salmonella food poisoning outbreak that occurred in Tokyo, Japan, in 2004. Staphylo- 
coccus aureus, Escherichia coli, and Proteus sp. strains were isolated from commercial foods in our institute.

\section{Incubation}

A Salmonella strain $04-137$ was isolated on a nutrient agar plate (Nissui Pharmaceuticals, Tokyo, Japan) and incubated at $37^{\circ} \mathrm{C}$ for about $20 \mathrm{hr}$. Colonies that grew well on the plate were inoculated in trypticase soy broth (Becton, Dickinson, and Company, Franklin Lakes, U.S.A.) and incubated with shaking at 100 strokes $/ \mathrm{min}$ and $37^{\circ} \mathrm{C}$ for about $20 \mathrm{hr}$. Cultured cells $\left(10^{10} \mathrm{CFU} / \mathrm{mL}\right)$ were washed twice with buffered sodium chloride solution (Nissui) containing 0.005\% $(\mathrm{v} / \mathrm{v})$ Tween 80 at $6,200 \times g$ and $10^{\circ} \mathrm{C}$ for $15 \mathrm{~min}$ and finally suspended in buffered peptone water (BPW), $\mathrm{pH}$ 7.2 (Oxoid, Basingstoke, UK) to afford the desired cell concentrations. S. aureus, E. coli, and Proteus cells were also prepared in the same manner as Salmonella cells.

The prepared cell suspension was diluted at various cell concentrations with pre-cooled BPW and sevenmilliliter portions of the dilution were then inoculated into glass test tubes $(15 \mathrm{~mm}$ inner diameter $\times 180 \mathrm{~mm}$ height). The sample suspensions were incubated at $39^{\circ} \mathrm{C}$ in an incubator with shaking at 100 strokes $/ \mathrm{min}$. At each one-hour interval a test tube was removed and cooled in ice water. In the selective medium experiment, Enterobacteriaceae Enrichment Mannitol (EEM) broth (Merck, Darmstadt, Germany) was used as the broth instead of BPW. Bacterial cell counts inoculated into the samples were measured with a plating method using nutrient agar plates (Nissui).

Dead Salmonella cells were prepared by heating the cell suspension prepared above $\left(10^{8} \mathrm{CFU} / \mathrm{mL}\right)$ at $75^{\circ} \mathrm{C}$ for $10 \mathrm{~min}$. The heated cell suspension was diluted appropriately with saline $(0.85 \%$ (w/v) sodium chloride solution) and then mixed into a viable cell suspension with a ratio of $1 / 100(\mathrm{v} / \mathrm{v})$, to make the final dead cell concentrations of $10^{4}, 10^{5}$, and $10^{6} \mathrm{cell} / \mathrm{mL}$.

\section{DNA extraction}

DNA extraction from a sample suspension was performed in an alkaline solution ${ }^{10)}$. Namely, a sample suspension prepared above $(0.2 \mathrm{~mL}$ each) was centrifuged at $6,200 \times g$ and $4{ }^{\circ} \mathrm{C}$ for $10 \mathrm{~min}$ and the resultant supernatant was removed with a capillary. Cells were mixed with $25 \mathrm{mM} \mathrm{NaOH}(0.1 \mathrm{~mL})$ and heated at $100^{\circ} \mathrm{C}$ for $5 \mathrm{~min}$. The mixture was neutralized with $80 \mathrm{mM}$ Tris $-\mathrm{HCl}$, pH $7.0(0.1 \mathrm{~mL})$ and centrifuged at $6,200 \times g$ and $4{ }^{\circ} \mathrm{C}$ for 10 minutes. The supernatant of the sample was used for real-time PCR as described below.

\section{Oligonucleotides}

The primers and fluorogenic probe for TaqMan realtime PCR were obtained from Sigma-Aldrich, Japan (Tokyo). The Salmonella-specific primers (Styinva-JHO2-left and -right) and probe [dual-labelled with 6carboxyfluorescein and 6-carboxytetramethylrhodamine] were those designed by Hoofar et al. ${ }^{11)}$ to amplify a 119-base pair fragment of the invasion (invA) gene
$(\mathrm{AN}: \mathrm{M} 90846)^{12)}$.

\section{TaqMan real-time PCR}

The Salmonella TaqMan real-time PCR was performed in a 25-microliter reaction volume. A sample (2.5 microliter) and a PCR mixture (total 22.5 microliters, finally consisting of $250 \mathrm{nM}$ Taqman probe, $300 \mathrm{nM}$ each primer, $1 \times$ Taqman Universal PCR Master Mix) (Applied Biosystems, Foster City, U.S.A.), prepared following the users' manual (Applied Biosystems), was plated in duplicate into wells of a microwell plate (Applied Biosystems). Two nontemplate controls were also added to the plate. Amplification was performed with an ABI Prism 7000 sequence detection system (Applied Biosystems). The operating conditions were the same as those of Knutsson et $a l^{7)}$ The value of threshold cycle $\left(C_{\mathrm{T}}\right)$, the cycle number at which the fluorescence is greater the fixed threshold, was estimated at the threshold of 0.2 .

\section{Statistical analysis}

Linear regression analysis, including slope and intercept estimations, was done using spreadsheet software, Microsoft Excel.

\section{Results}

\section{Increase kinetics of DNA during incubation}

When a Salmonella cell suspension was incubated in BPW, the growth curve of cells was an ordinary sigmoidal one (Fig. 1). In contrast with this curve, the $C_{\mathrm{T}}$ value of the suspension was reduced with time, generating a downward sigmoidal curve (Fig. 1). The straight portion, the slope, in the $C_{\mathrm{T}}$ curve was located between 2 to 6 hours of incubation in Fig. 1. That portion just corresponded to the logarithmic phase in the growth curve (Fig. 1). These results showed that the change in the $C_{\mathrm{T}}$ value was related to that in the number of the target cells in the suspension.

With lower initial viable cell number, the slope in the

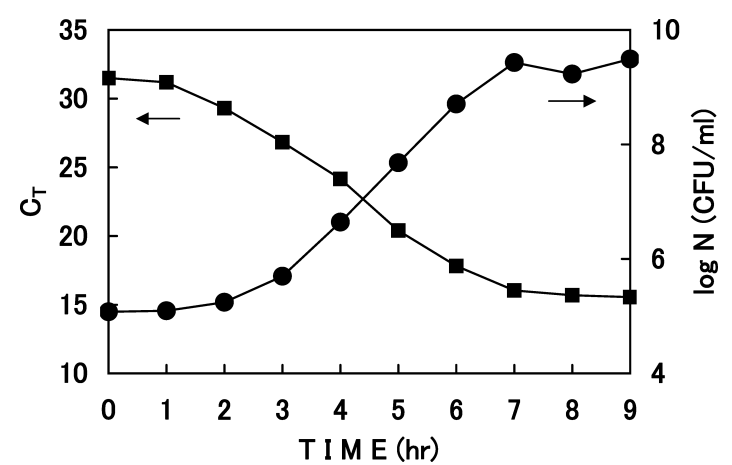

Fig. 1. Kinetics of cell growth and the $C_{\mathrm{T}}$ value of a Salmonella cell suspension in BPW during incubation

The initial cell concentration was $10^{5.1} \mathrm{CFU} / \mathrm{mL}$. Symbols: $\square, C_{\mathrm{T}}$; 0 , cell concentration, $N$. Arrows show the vertical axes corresponding to the curves. 


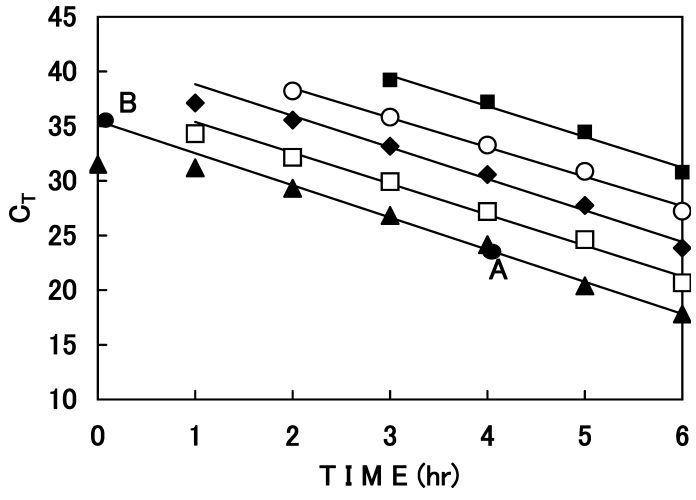

Fig. 2. Kinetics of the $C_{\mathrm{T}}$ value of a Salmonella cell suspension at various initial concentrations

The initial cell concentrations were $10^{5.1}(\mathbf{\Delta})$, $10^{4.1}(\square), 10^{3.1}(\diamond), 10^{2.1}(\bigcirc)$, and $10^{1.1}(\mathbf{\square}) \mathrm{CFU} / \mathrm{mL}$. Straight lines are the regression lines for the data points at those initial cell concentrations. Data at $10^{5.1} \mathrm{CFU} / \mathrm{mL}$ are the same as those in Fig. 1. Point $\mathrm{A}$ is a point at $5 \mathrm{hr}$ on the line and point $\mathrm{B}$ is the intercept of the line with the vertical axis at $10^{5.1} \mathrm{CFU} / \mathrm{mL}$

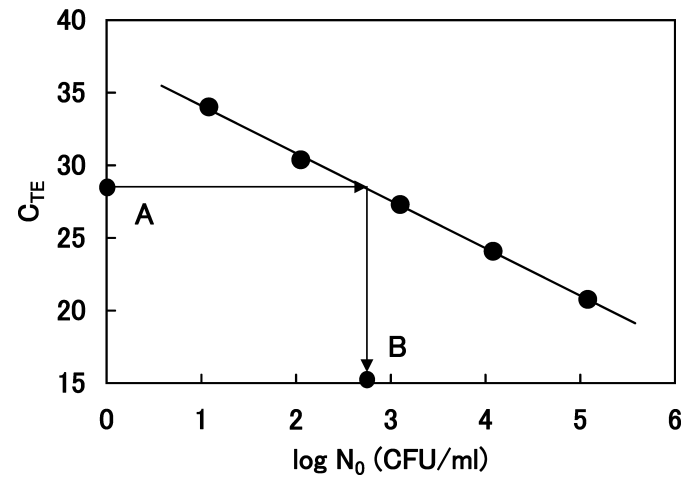

Fig. 3. Linear relationship between $C_{\mathrm{TE}}$ and the initial cell concentration

Closed circles are obtained from the data in Fig. 2. The line is the regression line for the data points. Points and arrows are described in the text.

$C_{\mathrm{T}}$ curve appeared later during the incubation (Fig. 2). The slopes at various initial cell concentrations were almost constant, being parallel to each other (Fig. 2); the values were $-2.9,-2.8,-2.9,-2.7$, and -2.8 at the initial cell concentrations of $10^{5.1}, 10^{4.1}, 10^{3.1}, 10^{2.1}$, and $10^{1.1} \mathrm{CFU} / \mathrm{mL}$, respectively. Here, the slopes with correlation coefficients over 0.99 were chosen. Since the $C_{\mathrm{T}}$ value over 40 was unstable, such high values were not analyzed in this study.

\section{Cell count estimation algorithm}

Based on the above findings, a novel method for estimation of viable Salmonella cell counts was developed. That is, the $C_{\mathrm{T}}$ value from the straight portion $C_{\mathrm{TE}}$ at a given time during the incubation was estimated using linear regression analysis. Let us name the time of estimation as $T_{\mathrm{E}}$. For example, in Fig. 2, point A on the regression line shows the estimated $C_{\mathrm{TE}}$ value at $T_{\mathrm{E}}=5 \mathrm{hr}$ at the initial cell concentration of $10^{5.1}$ $\mathrm{CFU} / \mathrm{mL}$. $C_{\mathrm{TE}}$ was found to be linearly related to the initial cell concentration with a correlation coefficient of 0.999 (Fig. 3). The regression line was $C_{\mathrm{TE}}=-3.27 \times$ $\log N_{0}+37.4$. Here $N_{0}$ is the initial cell concentration $(\mathrm{CFU} / \mathrm{mL})$ of a sample. With this equation, the initial viable cell concentration of a sample can be estimated from the observed $C_{\mathrm{TE}}$ value. To actually estimate the initial concentration, the above equation needs be transformed to $\log N_{0}=-0.31 \times C_{\mathrm{TE}}+11.4$. For example, when the $C_{\mathrm{TE}}$ value of a sample is 28 , the estimated cell concentration is $10^{2.7} \mathrm{CFU} / \mathrm{mL}$. Graphically, the estimation procedure is shown as arrows in Fig. 3. Point A shows an imaginary value of $C_{\mathrm{TE}}$ of a sample at $T_{\mathrm{E}}=$ $5 \mathrm{hr}$ and point $\mathrm{B}$ shows the initial cell concentration estimated with the method.

\section{Effect of dead cells}

When a sample cell suspension contained both viable and dead Salmonella cells, the kinetics of $C_{\mathrm{T}}$ changed with the concentration of dead cells (Fig. 4). With a higher dead cell concentration in the sample, $C_{\mathrm{T}}$ started at a lower value, because such a sample initially had more of the target DNA derived from the dead cells. But, as the viable cells grew with increasing incubation time, the value of $C_{\mathrm{T}}$ decreased linearly and converged into a single value.

The (downward) slope in the $C_{\mathrm{T}}$ curve was identical in all samples (Fig. 4). This is because the slope is based on the increase in the target DNA of the viable cells. Here the initial viable cell concentrations of all samples were the same. Thus, the slope in the decreasing $C_{\mathrm{T}}$ curve could be used for the viable cell concentration estimation as described above. As shown in a curve with an extremely high dead cell concentration $\left(10^{6.1} \mathrm{cell} / \mathrm{mL}\right)$ in Fig. 4, when the slope was horizontal or almost horizontal during the incubation time, that linear por-

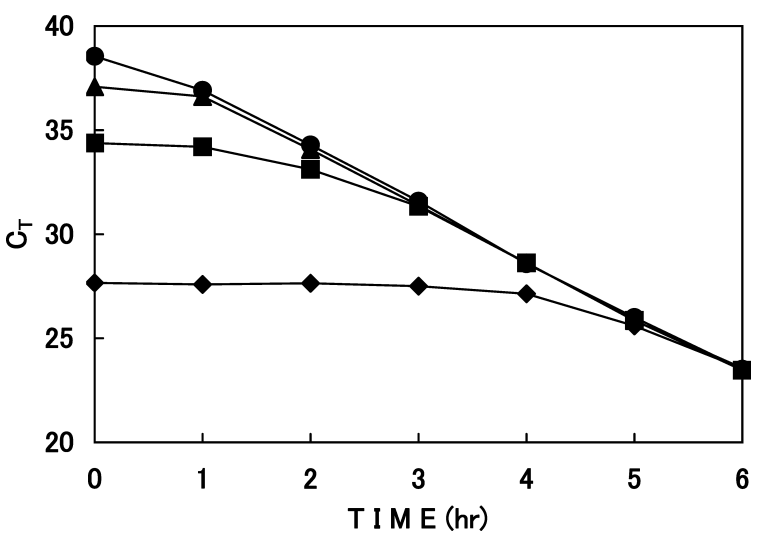

Fig. 4. Effect of dead Salmonella cells on the kinetics of the $C_{\mathrm{T}}$ value

The initial viable Salmonella cell concentrations were $10^{3.0} \mathrm{CFU} / \mathrm{mL}$ for all samples. Dead cell concentrations are $10^{6.1}(\bullet), 10^{5.1}(\mathbf{\square})$, and $10^{4.1}(\boldsymbol{\Delta})$ $\mathrm{CFU} / \mathrm{mL}$. The control $(\mathbf{O})$ does not contain dead cells. 


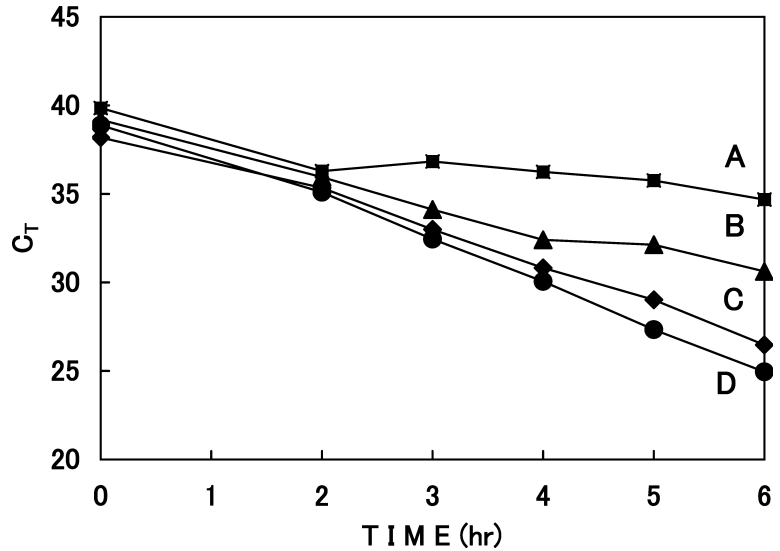

Fig. 5. Effect of bacteria other than Salmonella on the kinetics of the $C_{\mathrm{T}}$ value

The initial viable Salmonella cell concentration was $10^{2.9} \mathrm{CFU} / \mathrm{mL}$ for all samples. Combinations of E. coli and S. aureus cell concentrations are $10^{8.2}$ and $10^{7.5}(\mathrm{~A}), 10^{6.2}$ and $10^{5.5}(\mathrm{~B})$, and $10^{4.2}$ and $10^{3.5}$ (C) $\mathrm{CFU} / \mathrm{mL}$, respectively. The control (D) contains Salmonella cells only.

tion could not be used for the estimation.

\section{Effect of bacteria other than Salmonella}

The effect of presence of bacteria other than Salmonella at high cell concentrations in a sample cell suspension on the kinetics of $C_{\mathrm{T}}$ for Salmonella was studied, because food and clinical samples that are suspected to contain Salmonella are usually contaminated with other bacteria as well, at levels much higher than that of Salmonella. When a sample cell suspension contained E. coli as a gram-negative bacterium and S. aureus as a gram-positive one at concentrations much higher than that of Salmonella cells, the kinetics of $C_{\mathrm{T}}$ of the target microorganism changed with the concentrations of those bacteria (Fig. 5). The concentration ratios of those bacteria to Salmonella were about $10^{5}(\mathrm{~A}), 10^{3}(\mathrm{~B})$, and $10^{1}(\mathrm{C})$ in Fig. 5. As the concentrations of E. coli and $S$. aureus cells increased, the $C_{\mathrm{T}}$ curve deviated from the slope of the control with Salmonella only; the values of $C_{\mathrm{TE}}$ estimated from the slope of the $C_{\mathrm{T}}$ curve for samples B, C, and D in Fig. 5 were 32, 31, and 30, respectively, at $T_{\mathrm{E}}=4 \mathrm{hr}$. For sample A, the estimation was not done, because there was no downward slope in the $C_{\mathrm{T}}$ curve.

\section{Effect of selective medium}

Based on the results shown in Fig. 5, we tried to modify the culture medium to obtain a longer downward slope in the $C_{\mathrm{T}}$ curve for the estimation. A selective medium for the target organism, EEM, was studied as the culture medium at the presence of other bacteria, E. coli, Proteus sp., and S. aureus cells. Compared with the period of the slope in BPW ( $2 \mathrm{hr}$, from 2 to $4 \mathrm{hr}$ of incubation) (Fig. 6A), EEM prolonged the period ( $3 \mathrm{hr}$, from 2 to $5 \mathrm{hr}$ of incubation) (Fig. 6B). The four regression lines in Figs. 6A and B were almost identical. Thus, the $C_{\mathrm{TE}}$ values at $T_{\mathrm{E}}=4 \mathrm{hr}$ estimated from the regres-
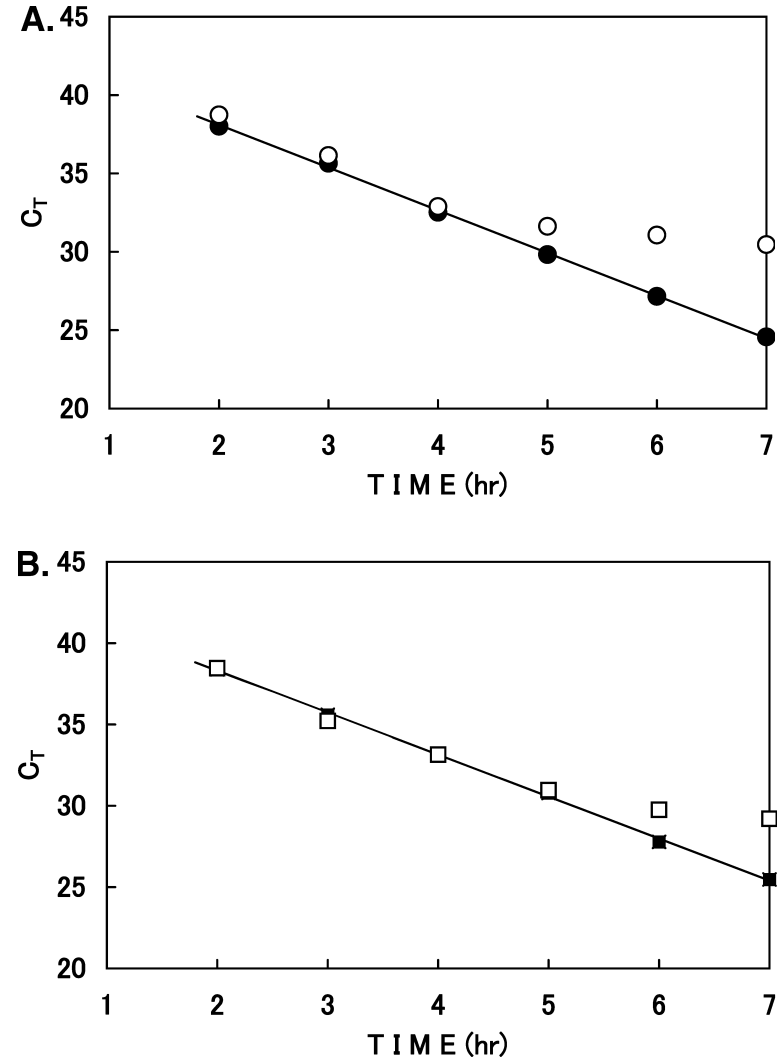

Fig. 6. Comparison between BPW (A) and EEM (B) in the kinetics of the $C_{\mathrm{T}}$ value

The initial viable Salmonella cell concentration was $10^{2.0} \mathrm{CFU} / \mathrm{mL}$ in all cases. Samples $(\bigcirc, \square)$ contain E. coli, Proteus sp., and S. aureus cells at concentrations of $10^{7.1}, 10^{7.2}$, and $10^{6.6} \mathrm{CFU} / \mathrm{mL}$, respectively, as well. The control $(\mathbf{0}, \mathbf{\square})$ contains Salmonella cells only. Gray and solid lines are linear regression lines for the samples and the controls, respectively.

sion lines were the same, being 33 for all the samples in BPW and EEM. These results showed that EEM made the slope in the $C_{\mathrm{T}}$ curve longs, suggesting that EEM could be a useful culture medium for this estimation method.

\section{Discussion}

The optimal growth temperature for the test strain in BPW prior to the real-time PCR procedure was first studied. Growth of cells suspended in BPW at the concentration of $10^{4} \mathrm{CFU} / \mathrm{mL}$ with shaking was recorded in terms of turbidity at $660 \mathrm{~nm}$ with a temperature gradient incubator (TN-2612, Advantec Toyo, Osaka, Japan) at constant temperatures ranging from 30 to $45^{\circ} \mathrm{C}$. As a result, the optimal value was $39.5^{\circ} \mathrm{C}$, followed by $38.5^{\circ} \mathrm{C}, 40.8^{\circ} \mathrm{C}$, and $37.5^{\circ} \mathrm{C}$ in that order. From this result, the preferred incubation temperature of the test strain was determined to be $39^{\circ} \mathrm{C}$. When four other Salmonella strains isolated from different food poisoning outbreaks in Tokyo were tested, their optimal growth temperatures were also all about $39^{\circ} \mathrm{C}$. In this study we developed a new estimation proce- 
dure for the initial viable cell concentration of the target microorganism in a sample (broth), using a quantitative real-time PCR method. We also established some characteristics of the $C_{\mathrm{T}}$ curve for the sample, as follows. When a sample contained only viable target cells, the slope in the $C_{\mathrm{T}}$ curve was long enough to estimate viable target cell counts, as shown in Figs. 2 and 3. With lower initial viable cell numbers, the slope appeared later during the incubation. Dead target cells in a sample increased the initial value of $C_{\mathrm{T}}$. For a sample containing bacteria other than the target microorganism, the value of $C_{\mathrm{T}}$ deviated from the slope of the control as the incubation time progressed.

The key point to accurately estimate $C_{\mathrm{TE}}$ in the $C_{\mathrm{T}}$ curve is how to obtain a "genuine" downward slope that is not affected by the factors described above or other unknown factors. Real food or clinical samples might include several kinds of microorganisms, dead target cells, and chemical or biological substances that affect the PCR reaction of the target DNA fragment. There might be several ways to avoid the effects due to those factors. Since the effect of microorganisms other than the target organism could not be ignored, use of a selective medium is expected to very useful.

In our preliminary study, highly selective media for Salmonella such as Rappaport-Vassiliadis Enrichment Broth medium (Oxoid) and Selenite Cystine Broth (Nissui) were also studied as the incubation medium. In those media, however, the growth of Salmonella itself was slower than that in BPW and EEM, giving $C_{\mathrm{T}}$ values higher than those with BPW and EEM. Moreover, there is a possibility that injured Salmonella cells might not grow in those highly selective media. Thus, those media cannot be recommended as the incubation medium at present.

This study revealed that EEM could be a good candidate for the incubation medium to estimate viable Salmonella cells in food/clinical samples with our method. That is, EEM did not affect the CTE values (with or without other bacteria) in comparison with the control (BPW), and it prolonged the slope (Figs. 6A, B). EEM contains effective ingredients to grow Salmonella well and selectively; bile and brilliant green inhibit grampositive bacteria and mannitol promotes Salmonella growth and inhibits Proteus and Providencia growth ${ }^{13)}$. Never the less, a better selective medium for Salmonella may be found in the future.

The value of $T_{\mathrm{E}}$ slightly affected the linearity between $N_{0}$ and $C_{\mathrm{TE}}$, as shown in Fig. 3 . The optimal $T_{\mathrm{E}}$ which gives the highest linearity between them was used to estimate $C_{\mathrm{TE}}$ in this study. The optimal $T_{\mathrm{E}}$ was $5 \mathrm{hr}$ in Fig. 3 and $4 \mathrm{hr}$ in Figs. 5 and 6. From these results, it was thought that the optimal $T_{\mathrm{E}}$ would be located at the second half of the slope in the $C_{\mathrm{T}}$ curves.

We found that the lower limit of this estimation method was $10^{\circ}(=1) \mathrm{CFU} / \mathrm{mL}$ (data not shown). That is, even if the number of viable target cells in a sample is only one, if that cell can grow during the incubation, the estimation method would be successful. As regards

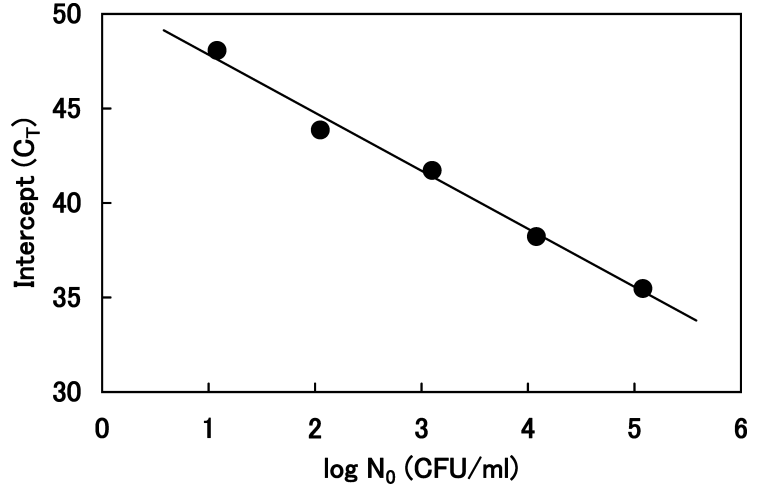

Fig. 7. Linear relationship between the intercept and the initial cell concentration

Closed circles are obtained from the data in Fig. 2. The line is the regression line for the data points.

the rapidity of the method, the incubation period was set at $6 \mathrm{hr}$ in most of our experiments. But, when a target organism grows slowly in a medium, the incubation period can be prolonged to get the slope in the $C_{\mathrm{T}}$ curve.

The estimation algorithm used in this study is a kind of the end point method with a value at a certain period $^{8), 9)}$. Another estimation algorithm was also developed using the intercept of a regression line for the slope in the $C_{\mathrm{T}}$ curve. As shown in Fig. 2, the slopes between 2 and $6 \mathrm{hr}$ at various initial concentrations were parallel to each other. The regression line for the slope portion intersects the vertical axis at the intercept. For example, point B in Fig. 2 is the intercept at the initial cell concentrations of $10^{5.1} \mathrm{CFU} / \mathrm{mL}$. With the lower initial cell concentration, the intercept was higher. There was a highly linear relationship between the intercept and the initial cell concentration with a correlation coefficient of 0.990 (Fig. 7). The regression line was: Intercept $=-0.31 \times \log N_{0}+51$. Using this relationship, we can also estimate the initial cell concentration of a sample from its intercept.

We are now studying the applicability of the estimation method to real food samples, such as raw chicken, which is one of the major causative food materials of Salmonella food poisoning outbreaks. Raw chicken inoculated with the test strain at a low cell concentration was used as an example. Here, a 10\% chicken homogenate with BPW was inoculated into BPW or EEM at the ratio of $1: 9$ for incubation, because the chicken itself might include substances that suppress the Salmonella growth and/or the PCR reaction. The results of this study will be presented soon. We will also validate our estimation method for other Salmonella strains.

\section{Acknowledgements}

We thank Dr. A. Kai and Ms. N. Konishi for their support in using the sequence detection system and the target strain. We also thank Dr. M. Takahashi for his 
technical advice on the real-time PCR method.

\section{Nomenclature}

$C_{\mathrm{T}}$ : threshold cycle

$C_{\mathrm{TE}}: C_{\mathrm{T}}$ estimated at $T_{\mathrm{E}}$

$N_{0}$ : initial cell concentration $(\mathrm{CFU} / \mathrm{mL})$

$T_{\mathrm{E}}$ : time for estimation (hour)

\section{References}

1) Hanna, E., Scott, C., Connor, J., Wang, H. H., Real-time polymerase chain reaction for the food microbiologist: technologies, applications, and limitations. J. Food Sci., 70, R49-R53 (2005).

2) Bassler, H. A., Flood, S. J. A., Livak, K. J., Marmaro, J., Knorr, R., Batt, C. A., Use of a fluorogenic probe in a PCR-based assay for the detection of Listeria monocytogenes. Appl. Environ. Microbiol., 61, 3,24-3,728 (1995).

3) Lyon, W. J., TaqMan PCR for detection of Vibrio cholerae O1, O139, non-O1, and non-O139 in pure cultures, raw oysters, and synthetic seawater. Appl. Environ. Microbiol., 67, 4,685-4,693 (2001).

4) Malorny, B., Paccassoni, E., Fach, P., Bunge, C., Martin, A., Helmuth, R., Diagnostic real-time PCR for detection of Salmonella in food. Appl. Environ. Microbiol., 70, 7,046-7,052 (2004).

5) Hsu, C.-F., Tsai, T.-U., Pan, T.-M., Use of the duplex TaqMan PCR system for detection of Shiga-like toxinproducing Escherichia coli. J. Clin. Microbiol., 43, 2,6682,673 (2005).
6) Josefsen, M. H., Jacobsen, N. R., Hoofar, J., Enrichment followed by quantitative PCR both for rapid detection and as a tool for quantitative risk assessment of foodborne thermotolerant Campylobacter. Appl. Environ. Microbiol., 70, 3,588-3,592 (2004).

7) Knutsson, R., Lofstrom, C., Grage, H., Hoorfar, J., Radstrom, P., Modeling of $5^{\prime}$-nuclease real-time responses for optimization of a high-throughput enrichment PCR procedure for Salmonella enterica. J. Clin. Microbiol., 40, 52-60 (2002).

8) Fujikawa, H., Morozumi, S., New estimation methods of bacterial concentration by measuring ATP changes during incubation. J. Food Hyg. Japan, 43, 155-159 (2002).

9) Fujikawa, H., Morozumi, S., Estimation of bacterial concentrations in commercial foods by measuring ATP changes during incubation. J. Food Hyg. Japan, 44, 8388 (2003).

10) Rolfs, A., I., Schuller, I., Finckt, U., Weber-Rolfs, I., "PCR: Clinical Diagnostics and Research”, Berlin, SpringerVerlag, 1992.

11) Hoorfar, J., Ahrens, P., Radstrom, P., Automated 5'. nuclease PCR assay for identification of Salmonella enterica. J. Clin. Microbiol., 38, 3,429-3,435 (2000).

12) Galan, J. E., Ginocchio, C., Costeas, P., Molecular and functional characterization of the Salmonella invasion gene invA: homology of InvA to members of a new protein family. J. Bacteriol., 174, 4,338-4,349 (1992).

13) Sakazaki, R. ed., "Shin Saikinbaitigakukoza Ge-II", 2nd Ed., Tokyo, Kindai Shuppan, 1990, p. 104-106. (ISBN-487402-468-8) 